\title{
Antitranspirant and Cryoprotectant Do Not Prevent Peach Freezing Injury
}

\author{
M.F. Aoun', K.B. Perry ${ }^{2}$, W.H. Swallow ${ }^{3}$, D.J. Werner ${ }^{2}$, and \\ M.L. Parker ${ }^{4}$ \\ Department of Horticultural Science, North Carolina State University, Raleigh, \\ NC 27695-7609
}

Additional index words. Prunus persica, cold tolerance, controlled environment

Two chemicals-FrostFree [50\% propylene block copolymer of polyoxyethylene, $50 \%$ propylene glycol (Plant Products, Vero Beach, Fla.)] and Vapor Gard [96\% di-1- $p$ menthene (pinolene, a terpenic polymer), $4 \%$ inert (Miller Chemical \& Fertilizer, Hanover, Pa.)] have been promoted as low-temperature protectants.

Vapor Gard did not prevent freezing damage to several tropical foliage plants (Fitzpatrick et al., 1986), several varieties of immature peaches [Prunus persica (L.) Batsch] in the field at rates double and equal to the manufacturer's recommended rate at $-5.0 \mathrm{C}$ (Matta and Mullenax, 1986), or several peach varieties in the field at postbloom or small fruit stages at -4.5C (Matta et al., 1987).

FrostFree did not protect peaches in the orchard (Matta et al., 1987) study, at full bloom at a controlled $-2.7 \mathrm{C}$, or in the field at -2.5 to $-4.5 \mathrm{C}$ (Rieger and Krewer, 1988), nor did it increase freezing resistance in developing grape (Vitis labruscana Bailey) shoots (Himelrick et al., 1991). In addition, tomato (Lycopersicon esculentum Mill.) or pepper (Capsicum аппиит L.) transplants were not protected at 0 to $-3.5 \mathrm{C}$ (field test) (Perry et al., 1992).

We determined 1) if FrostFree and Vapor Gard protect peaches at postbloom (petal fall) and small fruit stages at -1.0 to $-4.5 \mathrm{C}, 2$ ) the lowest temperature at which these products provide protection, and 3 ) the duration of the putative effectiveness of these products.

Six-year-old 'Legend' peach trees near Clayton, N.C. (lat. $35^{\circ} 40^{\prime} \mathrm{N}$, long. $78^{\circ} 30^{\prime}$, elevation $106 \mathrm{~m}$ ), were used. The controlledenvironment experiment was conducted in Spring 1990 and 1991 in the phytotron, North Carolina State Univ. The field test was conducted only in Spring 1990. A randomized complete-block design was used for both stud-

\footnotetext{
Received for publication 10 July 1992. Accepted for publication 15 Jan. 1993. The use of trade names in this publication does not imply endorsement by the North Carolina Agricultural Research Service of the products named, nor criticism of similar ones not mentioned. The cost of publishing this paper was defrayed in part by the payment of page charges. Under postal regulations, this paper therefore must be hereby marked advertisement solely to indicate this fact.

'Graduate Student.

${ }^{2}$ Professor.

${ }^{3}$ Professor, Dept. of Statistics.

${ }^{4}$ Assistant Professor.
}

ies, with four replications for the controlled and three for the field test.

Trees at full bloom were sprayed 5 Mar. 1990 in the field using a backpack sprayer with FrostFree at 0.0, 0.6, 1.1, or 2.2 liters.ha ${ }^{-1}$ (control, half, equal, and double the manufacturer's recommended rate). Branches were sprayed until just before runoff.

On 6 Mar. 1990, one day after spraying, 15 branches with at least 10 blossoms on each were cut from each of 16 trees. All branches were placed in jars with a forcing solution of $3 \%$ sucrose, $0.3 \%$ aluminum sulfate, and $0.7 \%$ ethanol in water. At the phytotron, three branches from each replication of the four treatments were put into five groups for treatment at $-1.0,-2.2,-3.3,-3.9$, or $-4.4 \mathrm{C}$. Branches were placed in two incubators (Sherer, Marshall, Mich.) at 4.4C. Temperature was lowered from 4.4 to $1.0 \mathrm{C}$ at $1.7 \mathrm{C} / \mathrm{h}$. At $1.0 \mathrm{C}$, the forcing solution was removed to prevent vascular tissue damage that might occur if the solution froze. Branches were placed at 1.0C in a growth chamber (GC) (Environmental Growth Chambers, Chagrin Falls, Ohio) .

The temperature in the $\mathrm{GC}$ was decreased from 1.0 to $-1.0 \mathrm{C}$ at $1.7 \mathrm{C} / \mathrm{h}$ and kept there for $1 \mathrm{~h}$. The branches at $-1.0 \mathrm{C}$ were moved back to an incubator at $1.0 \mathrm{C}$ and increased to $4.4 \mathrm{C}$ at $1.7 \mathrm{C} / \mathrm{h}$. The temperature in the $\mathrm{GC}$ was decreased from -1.0 to $-2.2 \mathrm{C}$ at $1.7 \mathrm{C} / \mathrm{h}$ and kept there for $1 \mathrm{~h}$. The branches at $-2.2 \mathrm{C}$ were moved back to an incubator at $-1 \mathrm{C}$ and increased to $4.4 \mathrm{C}$ at $1.7 \mathrm{C} / \mathrm{h}$. The same procedure was repeated for the remaining treatments. The forcing solution was replaced in the jars when the incubator reached 1.0C. At $4.4 \mathrm{C}$, branches were moved to a room at $20 \mathrm{C}$ and kept there for $24 \mathrm{~h}$.

Living and dead ovaries were counted on each branch. Ovaries and ovules were examined for freezing injury by dissecting the blossoms and observing tissue color. Turgid, lightgreen ovaries and white ovules were considered alive. Brown, desiccated ovaries and brown or black ovules were considered dead. Analysis of variance was conducted on these counts. Data from -1.0C were not used because all units survived. The temperature treatments in the phytotron were repeated on branches cut 4,8 , and 12 days after the 5 Mar. 1990 application to determine the potential duration of FrostFree.

The experiment was repeated in Spring 1991. FrostFree was applied at petal fall on 4
Apr. On 5 Apr., 10 branches were cut from each tree. At the phytotron, two branches from each of the four treatments were divided into the five temperature treatment groups. In contrast to 1990 , not all units survived at $-1.0 \mathrm{C}$, so these data were included in the 1991 analysis.

FrostFree application method and rates were the same as those for the controlledenvironment experiment. Vapor Gard was applied at 0.0, 0.6, 1.2, and 2.4 liters.ha ${ }^{-1}$ (control, half, equal, and double the manufacturer's recommended rate). On 19 Mar. 1990, with the anticipation of a frost, trees with flowers at the shuck split stage were sprayed to just before runoff. The following morning, the temperature dropped to $-2.2 \mathrm{C}$ for -1 h. Fruit were harvested 25 May 1990. Total fruit weight and weight of a random sample of 50 fruit were recorded for each tree. The weight of the 50-fruit sample was used to estimate total fruit count per tree as an indicator of flower survival. An analysis of variance was conducted on fruit count.

Controlled environment. The survival of flowers or developing fruit was similar for the FrostFree treatments and the control $(P<0.05)$ in both years and at all four periods after application (data not shown). The mean percent flower survival at all temperatures was higher at full bloom than at petal fall.

Field test. Neither chemical reduced lowtemperature injury of developing fruit ( 2 weeks after full bloom) when subjected to $-2.2 \mathrm{C}$ for $\approx 1$ h; i.e., the number of fruit harvested from treated and control trees was similar (data not shown). Means for four FrostFree and Vapor Gard application rates ranged from 870 to 1080 fruit per tree.

Neither chemical provided protection at -1.0 to $-2.2 \mathrm{C}$ or to immature peaches. Temperatures below $-2.2 \mathrm{C}$ and application rates also indicated that these products did not minimize low-temperature injury. Thus, our results and those of others demonstrate that these chemicals do not provide frost or freezing protection for peach flowers or developing fruit.

\section{Literature Cited}

Fitzpatrick, G., L. Griffith, and W.L. Maus. 1986. Evaluation of antitranspirants for cold protection in the nursery. Proc. Florida State Hort. Soc. 99:258-260.

Himelrick, D.G., R.M. Pool, and P.J. McInnis. 1991. Cryoprotectants influence freezing resistance of grapevine bud and leaf tissue. HortScience 26:406-407.

Matta, F.B., S. Little, and R.H. Mullenax. 1987. Effects of two chemicals on peach fruit survival following late spring frosts. Mississippi Agr. For. Expt. Sta. Res. Rpt. 12(18):1-3.

Matta, F.B. and R.H. Mullenax. 1986. Effects of Vapor Gard sprays on survival of developing peach fruit after a late spring frost. Mississippi Agr. For. Expt. Sta. Res. Rpt. 11(11):1-3.

Perry, K.B., A.R. Bonanno, and D.W. Monks. 1992. Two putative cryoprotectants do not provide frost and freeze protection in tomato and pepper. HortScience 27:26-27.

Rieger, M. and G. Krewer. 1988. Cryoprotectant and antitranspirant efficacy for frost protection of Prunus flower ovaries. Proc. Florida State Hort. Soc. 101:251-253. 